NBSIR 83-2778

\title{
Discovery of Heavy Hydrogen and Heavy Water
}

U.S. DEPARTMENT OF COMMERCE

National Bureau of Standards

Office of the Director of Administration

Library Division

Washington, DC 20234

October 1983

Internal Report

Prepared for:

U.S. DEPARTMENT OF COMMERCE

DOC tional Bureau of Standards

100 rary Division

.456

shington, DC 20234

83-2778

1983

C. 2 

Charles P. Saylor

U.S. DEPARTMENT OF COMMERCE

National Bureau of Standards

Office of the Director of Administration

Library Division

Washington, DC 20234

October 1983

Internal Report

Prepared for:

U.S. DEPARTMENT OF COMMERCE

National Bureau of Standards

Library Division

Washington, DC 20234

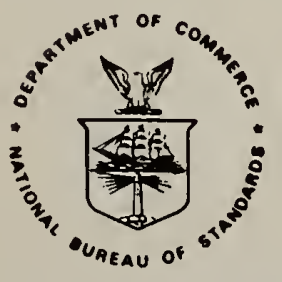

U.S. DEPARTMENT OF COMMERCE, Malcolm Baldrige, Secretary NATIONAL BUREAU OF STANDARDS, Ernest Ambler, Director 

The following brief account was prepared at my request by Dr. C. P. Saylor some years prior to his death in April 1982. It has been carefully reviewed by several present and former staff members, including former NBS scientist, Dr. F. G. Brickwedde, who participated with Dr. Harold C. Urey and others in the experiments and events described by Saylor. In his review Dr. Brickwedde, now Evans Pugh Research Professor of Physics emeritus at Pennsylvania State University, stated that "Dr. Saylor's paper covers an important part of the history of the discovery of deuterium that is not so well known ... and contains information important for the chemical historian. I hope you will have it published." 
In any single chemical element the atoms are exactly alike. Almostl They have the same charges, the same configurations, the same magnetic and electrical properties. They react in the same way chemically. But about three quarters of the natural elements have two or more kinds of atoms that differ slightly in weight. They are co-mingled, usually in fairly constant proportion. These atoms, differing only in mass, are known as isotopes (meaning that they belong in the same place on the periodic chart). The isotopes were long believed to be absolutely inseparable, although Keesom and van Dyk had presented credible evidence of some separation of neon isotopes by fractional distillation. Experimental evidence (later proved invalid) was strong that hydrogen, the lightest element, had no isotope.

In 19.31, however, two groups of scientists independently came to the conclusion that hydrogen might have an isotope of mass number 2. Vigorously and imaginatively they set to work. Before 1931 was ended both groups had achieved a partial separation of the "inseparable" constituents. They had established the existence of the heavy isotope of hydrogen. This was later named deuterium. In both cases the separations were performed at the National Bureau of Standards by bureau personnel, with NBS equipment. 
Harold C. Urey, who was then associate professor of chemistry at Columbia University initiated one of these projects. He decided that the most direct way of hunting a heavy isotope of hydrogen would be by distillation of the liquified element. In very few places in the world were they able to liquify hydrogen, let alone subject it to fractional distillation. Professor Urey hunted up a former Johns Hopkins University colleague, Ferdinand G. Brickwedde. Brickwedde was then chief of the Low Temperature Section of NBS. He liquified a large quantity of hydrogen and subjected it to partial reflux distillation. He delivered the "tails" to Columbia. G. M. Murphy, who was then a graduate student, together with Urey examined the spectrum of the higher boiling fraction and found that faint lines close to the normal lines of hydrogen were greatly enhanced. Their wavelengths differed from those of the normal Balmer series of ordinary hydrogen by the amount calculated for hydrogen of mass 2 . It was heavy hydrogen. Urey, Brickwedde, and Murphy prepared an announcement of their discovery in Physical Review. It was sent to the journal on December 5, 1931, and published in the first number in the new year.

Sometime between February 2, 1931, and the first signs of spring in Washington, the time (early April) when the first leaves appear on the willow trees, the other group began its work. Edward W. Washburn, chief chemist of the National Bureau of Standards, concluded that the theoretical evidence against the existence of a heavy isotope of hydrogen was faulty. He thought of many ways of attempting an enrichment and tried a significant portion of them. We only know of a few of them. He and his son sawed off the top of a willow tree in his backyard. Such garrotted trees can add 
tons of new growth in a single year. He and his associates, E. R. Smith and Mikkel Frandsen, messured the density of the residual water close to the roots of the rapidly growing plant. The same was done with jerusalem artichokes. The water from the leaves and twigs of young willow shoots, water from the Dead Sea, far from the Jordan River, and borax that represented the last drying up of inland salt lakes were tried. The water in all of these shows higher density by a few parts in a million than normal water. Ocean water has slightly more of the heavy isotope than terrestrial surface waters.

He considered the end products from the electrolysis of water and with Urey, in the spring of 1932, published a paper dealing with this and fractional distillation of water. With Smith he found that water absorbed by active charcoal had more of the heavy isotope. The important experiments, however, were those that used electrolysis.

When $98 \%$ of the water in a system is converted to gaseous elements, the residual water, after purification, has a density increased by 600 parts in a million. They were not absolutely certain, however, whether the increase in density was due to heavy hydrogen or to an increase of the known heavy isotope of oxygen. They redesigned the electrolysis vessels so that the released hydrogen and oxygen at all stages could be combined in many ways and each with "normal" hydrogen or oxygen. This lead to the astounding discovery by $E$. R. Smith that commercial oxygen was significantly enriched with respect to $0^{18}$. Ordinary liquid air is allowed to boil. The nitrogen evaporates carrying with it some of 
the $0^{16}$. That which remains is "heavy" by approximately 20 parts per million. This was the first known separation of isotopes by an industrial process. Power was turned on, probably in the new device, on December 9, 1931. There is some uncertainty whether the date refers to redesigned apparatus or the original one.

While it isn't clear which team first acquired evidence of a heavy isotope, there can be no doubt that the Urey, Brickwedde, and Murphy team was much farther along in December of 1931. They first acquired indisputable data to prove the existence of $\mathrm{H}^{2}$. They submitted their note first and published an authentic manuscript when the electrolytic experiments were in early stages. As happened, however, the method of separation used by Washburn, Smith, and Frandsen turned out to be more important. When our country went to work to develop a hydrogen bomb, the deuterium (heavy hydrogen) was made by the electrolytic method. When during World War II, the Germans endeavored to use heavy water as a neutron moderator for the production of an atomic bomb, they set up great electrolytic systems near the coast of Norway. We use it in the moderators of reactors. When we begin to get a major part of our industrial energy from nuclear fusion, it will probably utilize deuterium as a direct consequence of these discoveries.

Despite these dramatic applications, it can reasonably be argued that the most important consequences of the discovery of heavy hydrogen and heavy water have been the effects on research in the natural sciences. These have involved the physics of the nucleus and the atom, the entire 
question of isotope separation, sythesis of labeled organic compounds for studying biological processes, investigation of disease metabolisms, and other instances far too numerous to be detailed.

While the Urey team and the Washburn team began work in full independence early in 1931 , before the year was ended they knew of each other's activities. Even a friendly rivalry developed. The joint paper by Washburn and Urey probably grew from these associations. Urey received the Nobel Prize in chemistry in 1934 for the discovery of heavy hydrogen and, in the same year, Washburn (posthumously) received the Hillebrand prize in chemistry for his work on heavy water. 


\section{Significant References}

W. H. Keesom and H. van Dyk, Proceedings of the Royal Academy of Amsterdam, $34,42(1931)$.

H. van Dyk, Physica, 11, 203 (1931).

H. C. Urey, F. G. Brickwedde, and G. M. Murphy, Phys. Rev., 39, 164 (1932).

H. C. Urey, F. G. Brickwedde, and G. M. Murphy, Phys. Rev., 40, 1 (1932).

E. W. Washburn and H. C. Urey, Proc. Nat. Acad. Sci., 18, 496 (1932).

E. W. Washburn, E. R. Smith, and Mikkel Frandsen, J. Chem. Phys., 1, 288 (1933).

E. W. Washburn and E. R. Smith, J. Chem. Phys., 1, 426 (1933).

E. W. Washburn, E. R. Smith, and Mikkel Frandsen, J. Research, Nat. Bur . Stds., 11, 453 (1933).

E. W. Washburn and E. R. Smith, J. Research, Nat. Bur. Stds., 12, 305 (1934).

Edgar R. Smith, J. Chem. Phys., 2, 298 (1934).

E. W. Washburn, E. R. Smith, and F. A. Smith, J. Research, Nat. Bur. Stds., 13, 599 (1934). 
NAS.IILA IMEV, I.010)

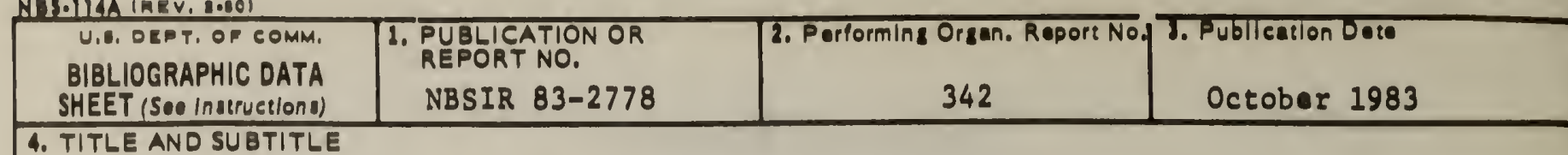

4. TITLE AND SUBTITLE

Discovery of Heavy Hydrogen and Heavy Water

5. AUTHOR(S)

Dr. C. P. Saylor

6. PERFORMING ORGANIZATION (If Jolnt of other thon NBS, instections)

NATIONAL DUREAU OF STANDARDS

DEPARTMENT OF COMMERCE

WASHINGTON, D.C. 20234

9. SPONSORING ORGANIZATION NAME AND COMPLETE ADDRESS (Streot, Cliy, Stoto, ZIP)

7. ContracuGrant No.

National Bureau of Standards

Library Division

Washington, D.C. 20234

10. SUPPLEMENTARY NOTES

V1gnette on the discovery of heavy hydrogen and heavy water, by Dr. Charles P.

Saylor prior to his death in 1982. Revlewed technically by Dr. C. Elsenhart,

Mr. W. R. T11ley, and Dr. F. G. Brickwedde

Document describes a computer prozram; SF.185, FIPS Soltware Summary, is atrached,

11. ABSTRACT (A 200-word of 10 s foctuol summery of most slenifleant informetion. If document includes o slenlfleont blbllogrophy or llteroture supvey, mention it here)

Eleven olgniflcant references are 118 ted at the end of the article.

The role of Dr. H. C. Urey, F. G. Brickwedde, G. W. Murphy, E. W. Washburn, E. R. Smith, and M. Frandsen in the discovery of heavy hydrogen and heavy water.

12. KEY WORDS (SIX to twelve entrles; olphobet/cal order; copltallze only proper nomes; ond seporote key words by semicolons) Discovery of heavy hydrogen and heavy water; F. G. Brickwedde; M. Frandsen;

H. G. Urey; G. M. Murphy; E. R. Smith; E. W. Washburn.

\section{AVAILABILITY}

[X] Unlimited

For Official Distribution. Do Not Release to NTIS

$\square$ Order From Superintendent of Documents, U.S. Government Printin\& Office, Washington, O.C. 20402.

X] Order From Nationai Technical Information Service (NTIS), Springfieid, VA, 22i6i
14. NO. OF

PRINTED PAGES

9

15. Price

$\$ 7.00$ 

